\title{
Identifying Risks for Better Project Management between Two Different Cultures: The Chinese and the Spanish
}

\author{
Rocío Rodríguez-Rivero ${ }^{1, *(\mathbb{D}}$, Isabel Ortiz-Marcos ${ }^{1}{ }^{\mathbb{D}}$, Luis Ballesteros-Sánchez ${ }^{1}$ and \\ Xabier Martínez-Beneitez ${ }^{2}$ \\ 1 Department of Organization, Business Administration and Statistics, Universidad Politécnica de Madrid, \\ C/José Gutiérrez Abascal 2, 28006 Madrid, Spain; isabel.ortiz@upm.es (I.O.-M.); \\ luisignacio.ballesteros@upm.es (L.B.-S.) \\ 2 Taiger Spain, C/Apolonio Morales, 13, 28036 Madrid, Spain; xabier.martinez@taiger.com \\ * Correspondence: rocio.rodriguez@upm.es
}

Received: 20 August 2020; Accepted: 12 September 2020; Published: 15 September 2020

check for updates

\begin{abstract}
Business globalization causes all project managers, sooner or later, to face the challenge of understanding cultural differences. Identifying the risks associated with these differences has become an essential task today when discussing international projects. This paper shows how to improve the management of projects carried out in China by Spanish organizations, identifying risks related to differences between societies. To determine this set of risks, the cultural dimensions of Hofstede and Meyer were analyzed for the case of China and Spain, as well as the most critical values of the World Value Survey between both cultures. From there, and thanks to work done with a focus group formed of 29 Spanish project managers who are experienced in working in projects developed in China, risks were identified and classified into categories considering cultural dimensions. The results obtained show a record of risks of great interest for organizations working in international contexts, mainly in China. They reveal, in addition, the importance of considering this type of risks related to cultural differences, which have rarely been treated before.
\end{abstract}

Keywords: risk management; project management; values; national culture; China

\section{Introduction}

Understanding culture is one of the most critical challenges today due to globalization and its importance in business. Since the 1990s, leaders of organizations have crossed borders in all dimensions of business and government more rapidly and continuously than ever before.

In this new context, sustainability and sustainable development have attracted the attention of the scientific community, and cross-cultural adjustment (CCA) is considered to be a key theme in human resource management [1]. It applies not only to the management of human resources, but to the whole organization, as the main management system standards, like the International Organization for Standardization (ISO) state. Martínez-Perales et al. [2] studied the correspondence between these management system standards and sustainability variables revealing the strong relationship between them. Thus ISO 14001:2015 for environmental management [3] is considered a fundamental pillar of sustainability in organizations, and ISO 9001:2015 for quality management [4] already refers to the importance of the relative risks of the relationships between different stakeholders. These risks are more significant when it comes to international relations due to the associated cultural differences. Furthermore, in this standard, the concept of risk-based thinking appears for the first time, with which it is clarified that every risk has an intrinsic opportunity and a threat. 
Specifically, risk management has its special recognition within these standards with the ISO 31.000:2018, a guide on how to manage the risks faced by organizations [5]. This standard establishes the following four steps for risk management: (i) risk identification; (ii) risk analysis; (iii) risk assessment; (iv) risk treatment. This paper remains in the first step since for the analysis, assessment, and treatment it is essential to take into account the criteria of each organization. In this research, 29 professionals have participated from different organizations.

Focusing on the case of China, the importance of the risks associated with international environments has been recently highlighted in projects, such as the "Belt and Road" initiative, where the more important risks are country and cross-cultural risks [6].

This research focuses on China, not only because it is one of the major developing economies in the world, but also because it is characterized by a unique, centuries-old culture that makes the direct transfer of Western relationship business principles questionable [7] and surrounded by risks.

The research has the main aim of increasing project success levels for Spanish companies working in China through better knowledge of their intercultural differences, and the identification of the main risks related to these differences. Three specific objectives support that goal.

The first specific objective is to know what previous studies established about intercultural differences and how China and Spain are defined according to these studies.

The second specific objective is to analyze the results from the World Values Survey (WVS), highlighting China and Spain's most critical values.

The third specific objective is to identify, through a focus group with 29 Spanish project managers experienced in leading projects in China, what the most critical risks are that could jeopardize a project from an intercultural point of view.

During the training session given in the focus group and the discussions held in search of consensus or the identification of the risks, project managers have achieved a better knowledge of Chinese culture and of the existence of cultural differences. It has allowed project managers to identify 20 risks considered as valuable findings to start working with risk management associated with cultural differences in their organizations as a first step towards improving the performance of Spanish projects in China.

\section{Literature Review}

\subsection{Project Management}

The project management discipline is relatively modern. It is characterized by methods and tools to improve performance, control, and results in adapting specific management techniques [8]. Project management involves five process groups as identified in the Project Management Book of Knowledge (PMBOK) [9]: project initiation, planning, execution, monitoring and control, and closure. In the same reference, it is established that project management contains 10 areas of knowledge: integration, scope, time, cost, quality, resources, communication, risk, procurement, and stakeholders.

Attention to these processes and knowledge areas addresses the need for change, which is reflected in the considerable number of research articles devoted to exploring these issues and which promote the permanent link between theory and practice [10]. The number of articles published around these processes and areas of knowledge from different perspectives is increasing every year.

The need to rethink the project management discipline has also been highlighted to achieve better results effectively [11-14]. Some authors have also noted that it is required to consider other aspects as sustainability [14-18] and the relationship between sustainability and different areas of knowledge of project management $[2,19]$. Other authors highlight the importance of project manager competences in achieving project success [20-29].

The approach of the concept of sustainability to the field of project management (PM) has been considered with interest in recent years by researchers exploring sustainability as a success factor in a 
project. Certification of management systems (with their correspondence to sustainability variables) has a positive impact on project success [2].

In this context, the importance of risk management has been exposed [30,31], in some cases with interesting discussions between risks and uncertainties in project management [32-37].

Both in research more focused on the figure of the project manager and in studies focused on risks, it is increasingly common to find interesting links with cultural aspects [38-41].

\subsection{Cultural Dimensions}

One of the most relevant researchers to study the nature and complexity of the cultural differences is the Dutch sociologist Geert Hofstede, whose work has inspired other interesting studies and remains predominant in this field. Hofstede defined six groups to differentiate country cultures, which are known as the Hofstede dimensions of national culture [42]:

1. Power distance expresses the degree to which the members of a society accept a hierarchical order. This is correlated to one of the dimensions of the analysis of the political system [43];

2. Individualism versus collectivism represents the preference for a narrow or wide social framework, where the members of a society are expected to care only for themselves or the whole group. This is correlated to the gross domestic product (GDP);

3. Masculinity versus femininity measures the preference for a more competitive or cooperative society. Femininity is correlated to the national incomes spent in human development aid;

4. Uncertainty avoidance refers to the feeling of discomfort with ambiguity or uncertainty. This is correlated to one dimension of the mental health study of Lynn and Hampson [44];

5. Long-term orientation, a fifth dimension that was added in 1991 on the basis of research in the Far East by Canadian psychologist Michael Harris Bond and supported by Hofstede [45], represents Confucian thinking. It means how a society deals with its past and the challenges of the future. In the 2000s, research by Michael Minkov using data from the WVS [46] made a new calculation of this fifth dimension possible;

6. Indulgence versus restraint, a sixth dimension which was added in 2010 by Michael Minkov [42], distinguishes whether or not a society allows the free expression of feelings.

Hofstede's work has inspired some other authors to keep researching the analysis of these dimensions [47], or their influence to some essential areas of knowledge in project management, such as communication management, highlighting the empirical study of Müller and Turner [48] or the Lewis Model [49].

In recent years, the American professor Erin Meyer [50] has also compared some countries based on their cultural patterns and demonstrated again the importance of understanding culture to manage any kind of international project today. Her cultural map drew on the work of previous researchers, most notably Hofstede et al. [42] and Trompenaars [51] and created a framework that examines communication on multiple dimensions and locates various national cultures on each. The indicators that Meyer proposed are the following:

1. Communicating: distinguished between low-context for countries where communication is precise and high-context for some countries where communication is sophisticated;

2. Evaluating: shows how people in different cultures manage negative criticism or negative feedback, using direct or indirect negative feedback;

3. Persuading: establishes two styles of reasoning, principles-first or applications-first;

4. Leading: this indicator is also considered by Hofstede by the concept of power distance. In this case, Meyer uses the word egalitarian instead of low-power distance and hierarchical instead of high-power distance;

5. Deciding: refers to decision-making responsibility, consensual, or individual;

6. Trusting: trust may be task-based or relationship-based; 
7. Disagreeing: demonstrates the differences between confrontational and confrontation-avoiding societies;

8. Scheduling: differentiates linear-time from flexible-time cultures.

\subsection{Comparison between China and Spain}

Focusing on the application of both analyses, Hofstede and Meyer, of China and Spain, firstly, some key cultural aspects of both cultures are presented.

China and Spain are very different countries at first sight. China is a vast communist country with a population of more than one billion, and with thousands of years of culture. Spain is a small capitalist country with less than 50 million people that was invaded and conquered several times, adopting features of every culture (Roman, Ottoman, Arab).

Based on the quantitative works of Hofstede, Figure 1 shows a general overview where differences can be observed between China and Spain. Significant gaps appear in every dimension, but it is interesting to highlight the high position of China in power distance, collectivism, and long-term orientation, and the high position of Spain in uncertainty avoidance. They constitute the main characteristics of these cultures.

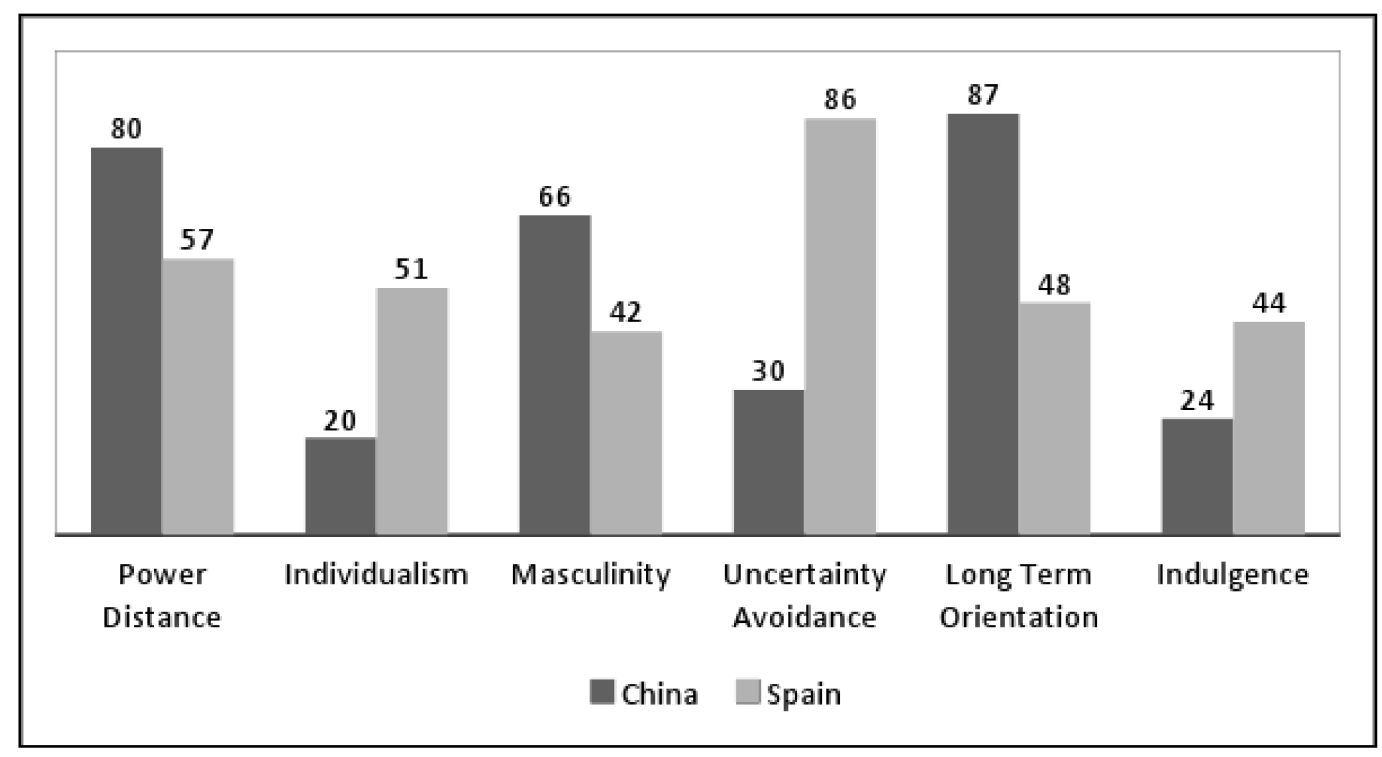

Figure 1. Comparison between China and Spain based on the Hofstede model.

Thus, China is a very hierarchical society, with an authoritarian regime, which precisely contributes to promoting collectivism watching over all members of society. In addition, China is the birthplace of Confucianism, which gave rise to long-term orientation. Therefore, when doing any project in China or with Chinese organizations, it is necessary to take into account these aspects and, for example, organize meetings between people of the same level. Likewise, having a well-defined schedule is essential to meet the need for long-term orientation.

On the other hand, in Spain, mistakes are not seen as learning, but as a failure. An example of this is the entrepreneurship index. In 2018, $10 \%$ of citizens in the most developed countries were involved in an entrepreneurial initiative, compared to $6.4 \%$ of Spaniards [52]. Therefore, for Spain, it is important to carefully define the contracts and the clauses of possible deviations. This could be a source of conflict that should be monitored because in China, emphasis is often more on ethics than on standards, as previous studies have shown [39].

In the same line, Figure 2 presents the comparison between Chinese and Spanish culture, according to the Meyer model. In the context of communication, Spanish culture gives more importance to non-verbal language, while indirect style is preferred in Chinese culture, where body language is not usual, and a calm manner controls the meetings. In China, it is customary to ask questions to label 
the other person to facilitate a relationship with them. In Spanish culture, starting a conversation by asking the other person's age and salary is inconceivable [53]. Concerning negotiations, Chinese culture is monochronic, and commitments to dates are prioritized. In contrast, in Spanish culture, which is polychronic, there is a tendency to start several tasks at once, and deadlines are flexible [53]. In a professional relationship before or during the execution of a project, it is advisable to consider these differences that are so closely related to communication management and task implementation.

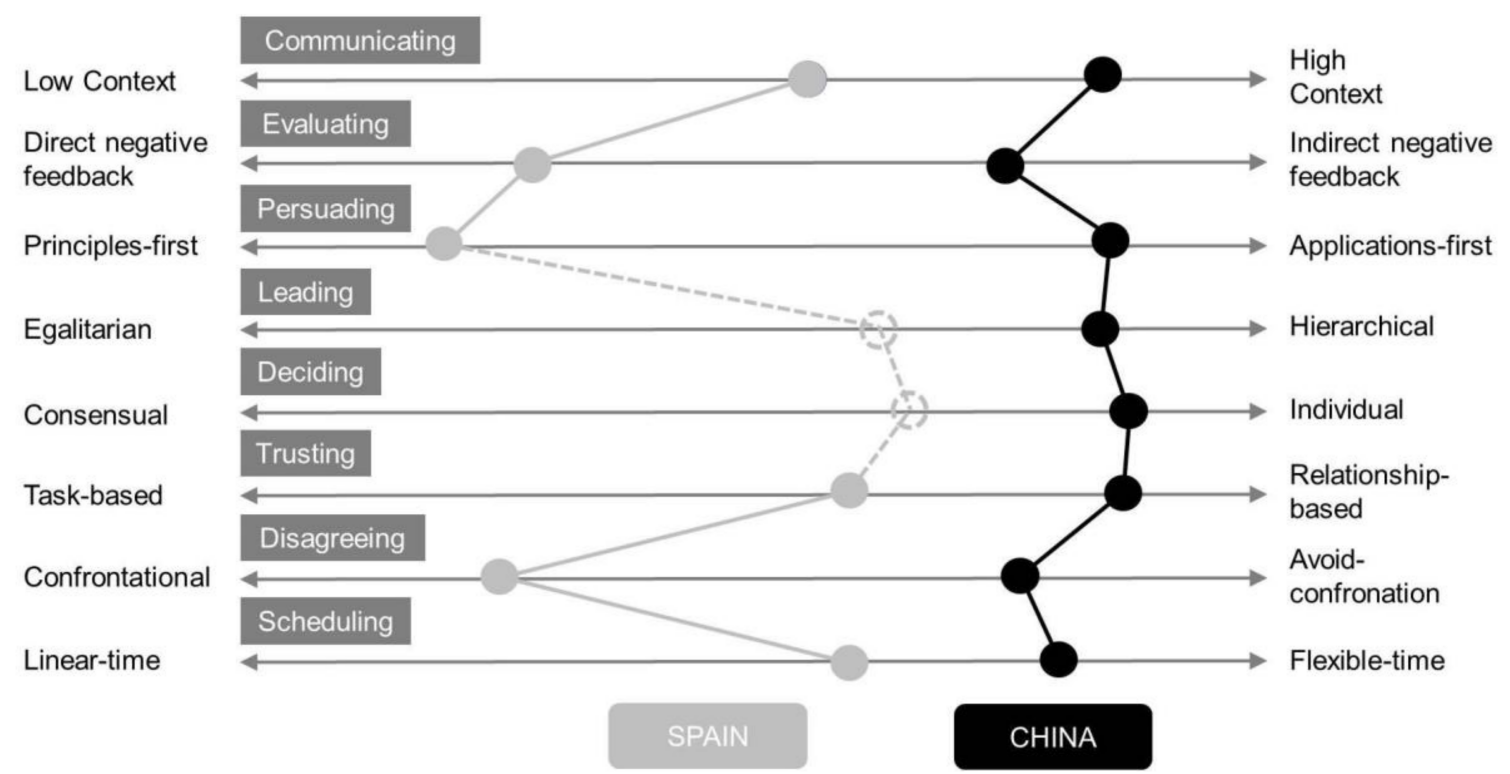

Figure 2. Comparison between China and Spain based on the Meyer model. Note: Discontinue marks are estimated by authors since they are not included in Meyer's study.

As some of these dimensions are related, in previous works of the authors, an attempt to synthesize both Hofstede and Meyer's cultural approaches was made [41]. These dimensions were the following:

1. Power distance-leadership: the relationship between leaders and subordinates;

2. Long-term orientation-scheduling: the conception of time, planning, and future orientation;

3. Individualism: involvement in a team;

4. Uncertainty avoidance-deciding: the confrontation of risk and the capability to assume risk and make decisions;

5. Communication (listening skills, negative feedback, disagreement): the connection between people and information channels;

6. Persuading: the power of influence between people;

7. Trusting: the capability to rely on others.

In addition to the Hofstede and Meyer's comparisons between China and Spain, some particularities of Chinese culture are explained next. This is because Chinese culture is considered to hold values that differ not only from Spanish values but also from most of the values of Western cultures. This includes ways of doing things that are often very different from those of the West [41,54-56]. Chinese culture is a collectivistic culture. Collectivism is the idea that an individual's life does not belong to them, but to the group or society of which they are merely a part [57]. This attitude is rooted in benevolence and conformity [58]. Benevolence focuses on concern for the welfare of others in everyday close interaction. Conformity is derived from the requirement that individuals inhibit their inclinations that may be socially disruptive.

Understanding the particularities of Chinese culture is indispensable when doing business with China. There are studies that demonstrate, for example, the importance of goal interdependence and cooperation between Chinese employees and foreign managers [59]. 


\subsection{Risk Perception Considering the Cultural Approach}

The notion of risk is of high interest in several contexts and is generally considered as an effect of uncertainty and, consequently, as a measure of deviation from an anticipated outcome [60-62].

There is a lack of objectiveness within current risk-scoring processes [63]. To understand these differences, the importance of considering the cultural influence when managing risks has already been highlighted by researchers [39]. De Camprieu et al. [64] published the results of an empirical study and proved that project managers from different cultural horizons differ in the way they assess risk.

Some authors have also highlighted the importance of transferring experiential knowledge within the cultural boundary to reduce uncertainty [65]. The international strategy literature already identified during the last decades of the twentieth century that the cost of doing business abroad stems mainly from cultural differences between the home and host countries [66,67].

Other authors have reminded that global sustainability goals cannot realistically be achieved without strategies that build on multiscale definitions of risks to wellbeing. This has been proven through the use of a cultural consensus analysis [68].

Monteiro de Carvalho et al. [69] investigated the effects of project management on project success under the parameters of scheduling, cost, and margins. The results showed that cross-country analysis has a significant explanatory effect.

Business and project risks are perceived and managed differently in distinct national cultures. The more different the culture is, the more diverse risk perception is, and the more complicated their management becomes $[39,70]$.

Rodríguez-Rivero et al. [41] determined that most of the risks that are associated with multicultural contexts can be mitigated if they are appropriately identified. Other researchers have sought to determine the cultural values that affect individuals' preferences of specific conflict-handling styles or how these values affect organizations [71]. Their results contribute to a more comprehensive understanding of the role of culture and emotional intelligence in conflict handling [72].

Liu [73] examined how cultural differences moderate the effectiveness of an organization's enterprise risk management (ERM) program in sustainable decision making. She found that Chinese participants were characterized by a stronger prevention focus, whereas American participants were characterized by a stronger promotion focus.

The inclination of people to view their own life with a positive perspective is more evident in individualist cultures than in collectivistic ones [74]. Additionally, Autio et al. [75] found that cultures with a high collectivism dimension have practices negatively associated with entrepreneurial entry but, on the other hand, positively associated with entrepreneurial growth aspirations.

\section{Materials and Methods}

The first step in this research consisted of reviewing cultural studies and analyzing both cultures. Previous studies on cultural differences allowed the authors to select Hofstede [76] and Meyer's dimensions [50] to establish a comparison between China and Spain.

The second step focused on the analysis of the results from the World Value Survey (WVS). This database was selected because it is a global network of social scientists who are studying changing values and their impact on social and political life. The WVS provides data to analyze the most critical values of both cultures, Chinese and Spanish. Moreover, WVS data are publicly available without charge. The data were downloaded to carry out the analysis that is presented here.

The current research was conducted using the WVS-6 (2010-2014) [77]. The WVS-7 (2015-2020) questionnaire has been completed with the inclusion of new topics such as justice, moral principles, corruption, accountability and risk, migration, national security, and global governance, and even contributed to the monitoring of the Sustainable Development Goals.

Not all values from WVS-6 data have been considered in this research-only those related to cultural dimensions. This was done through a detailed analysis of the values present in the database. During this step of the study, a program was designed with MATLAB software to analyze the database's 
responses considering all of the characteristics of the survey. To determine the most critical values, the authors established as a limit those that had a value below $10 \%$ or above $90 \%$ of the rest of the world's values. Thus, if a Chinese value is included within the highest $10 \%$ of values or lowest $10 \%$, it is considered as critical value and carried over for subsequent analysis.

The same analysis was done in Spain with these critical values to compare the two societies.

The third step, once critical values were highlighted, was to identify risks linked to critical values in a project context. It may be noted that 29 Spanish project managers with more than 10 years of experience each leading projects in China participated in the risk identification process in a focus group with researchers. The sectors in which these professionals work are presented in Figure 3.

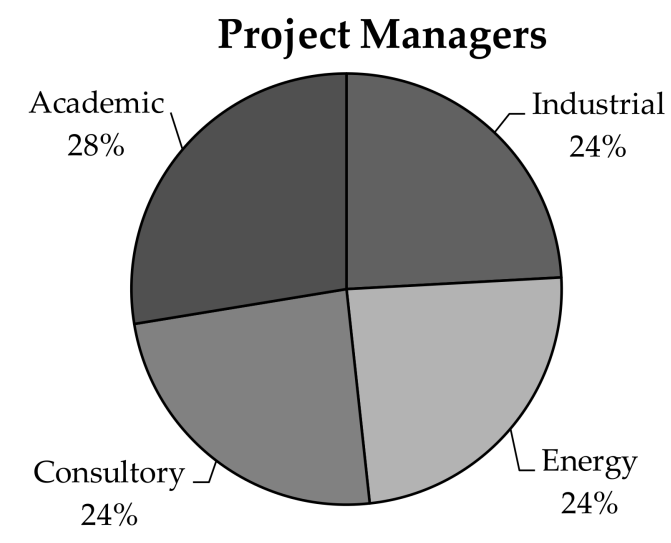

Figure 3. Percentage of project managers per sector.

During the focus group, and prior to the identification work, a brief presentation was made of the results of the previous studies by Hofstede and Meyer, as well as why the most critical values from the WVS should be used as a source of risks. For the identification, the dimensions they should work with were presented, giving the freedom to add or remove any. Once they were agreed upon, the risks were identified. This identification was done dimension by dimension, and only those risks were included on which the whole group agreed. The same was done for the assignment of values that could be related.

\section{Analysis of the World Value Survey Data}

The WVS started in 1981 and is conducted in almost 100 countries that contain nearly 90 percent of the world's population. It uses a standard questionnaire that includes 290 questions to measure cultural values, attitudes and beliefs toward gender, family, and religion, attitudes toward and experience of poverty, education, health and security, social tolerance, and trust, attitudes toward multilateral institutions, and cultural differences and similarities between regions and societies. Some of these questions are inspired by Schwartz's dimensions for comparing cultures [78-80].

Over the years, the WVS has demonstrated that people's beliefs play a key role in economic development, the emergence and flourishing of democratic institutions, the rise of gender equality, and the extent to which societies have an effective government. Likewise, other studies have already highlighted the importance of the presence of national values in any project or international negotiation [81].

Hofstede [82] highlights the power of the WVS database and the importance of improving research on the cultural context. Based on WVS data and previous work, Minkov and Hofstede made an interesting contribution to this field [42].

Although China is one of the largest countries in the world and the most populated, it is still possible to identify specific core cultural values that are shared by Chinese people no matter where they live [83]. 
The values that have been determined to be critical to Chinese society from the analysis of the WVS data with the MATLAB program designed for this research are shown in Table 1. The position of China relative to other countries is shown in the third column. This means the position of its score in the value compared to the scores of the other countries for the same value. The rank of Spain relative to other countries is also shown to compare later with China since the research deals with the opinion of project managers from this country. The means China, Spain, and the remaining countries are presented to indicate their differences. Critical Chinese values are arranged by position, with the highest values (>90\%) shown first and the lowest ones following $(<10 \%)$.

Table 1. Critical values for China from the World Values Survey (WVS).

\begin{tabular}{|c|c|c|c|c|c|c|}
\hline Value Id. & Value Definition & $\begin{array}{l}\text { Chinese Position/ } \\
\text { Total of Countries }\end{array}$ & $\begin{array}{l}\text { Spanish Position/ } \\
\text { Total of Countries }\end{array}$ & $\begin{array}{c}\text { Chinese } \\
\text { Mean }\end{array}$ & $\begin{array}{l}\text { Spanish } \\
\text { Mean }\end{array}$ & $\begin{array}{l}\text { World's } \\
\text { Mean }\end{array}$ \\
\hline 63 & $\begin{array}{l}\text { Aims of the respondent (Second } \\
\text { choice): Maintaining order in } \\
\text { the nation }\end{array}$ & $1 / 60$ & $24 / 60$ & 38.3 & 23.1 & 22.7 \\
\hline 79 & $\begin{array}{l}\text { Schwartz: Tradition is important } \\
\text { to this person; to follow the } \\
\text { customs handed down by one's } \\
\text { religion or family }\end{array}$ & $4 / 60$ & $17 / 60$ & 18.92 & 16.27 & 14.99 \\
\hline 115 & $\begin{array}{l}\text { Confidence: The government (in } \\
\text { your nation's capital) }\end{array}$ & $4 / 60$ & $52 / 60$ & 30.49 & 19.04 & 23.56 \\
\hline 73 & $\begin{array}{l}\text { Schwartz: It is important to this } \\
\text { person to have a good time; to } \\
\text { "spoil" oneself }\end{array}$ & $5 / 60$ & $27 / 60$ & 21.45 & 18.47 & 17.86 \\
\hline 117 & Confidence: Parliament & $5 / 60$ & $28 / 60$ & 28.3 & 21.05 & 21.69 \\
\hline $160 \mathrm{a}$ & $\begin{array}{l}\text { I see myself as someone who: } \\
\text { is reserved }\end{array}$ & $23 / 25$ & No data & 15.87 & No data & 20.83 \\
\hline $160 \mathrm{i}$ & $\begin{array}{l}\text { I see myself as someone who: } \\
\text { gets nervous easily }\end{array}$ & $24 / 25$ & No data & 15.61 & No data & 19.25 \\
\hline 124 & $\begin{array}{l}\text { Confidence: Charitable or } \\
\text { humanitarian organizations }\end{array}$ & $58 / 60$ & $28 / 60$ & 18.87 & 25.93 & 24.87 \\
\hline $130 *$ & $\begin{array}{l}\text { Political system: Having a } \\
\text { democratic political system }\end{array}$ & $59 / 59$ & $6 / 59$ & 25.10 & 35.53 & 31.09 \\
\hline 9 & Importance in life: Religion & $60 / 60$ & $54 / 60$ & 14.34 & 20.50 & 30.53 \\
\hline $106^{*}$ & $\begin{array}{c}\text { How much you trust: People of } \\
\text { another religion }\end{array}$ & $60 / 60$ & $1 / 60$ & 9.08 & 27.17 & 20.73 \\
\hline $107^{*}$ & $\begin{array}{c}\text { How much you trust: People of } \\
\text { another nationality }\end{array}$ & $60 / 60$ & $1 / 60$ & 13.23 & 28.32 & 27.53 \\
\hline 108 & Confidence: The Churches & $60 / 60$ & $56 / 60$ & 13.23 & 19.94 & 27.53 \\
\hline 143 & $\begin{array}{l}\text { Thinking about the meaning and } \\
\text { purpose of life }\end{array}$ & $60 / 60$ & $58 / 60$ & 23.55 & 27.43 & 31.15 \\
\hline
\end{tabular}

Most of the questions through which the values are scored are grouped by categories identified in the WVS. For example, those categories with the most values include "important in life", "satisfaction with your life", "aims of a country", "aims of respondent", "future changes", "Schwartz", "political action", "how much you trust", "confidence", "political system", "social position", "I see myself as someone who", or "how frequently do the following things occur in your neighborhood". In the case of the category dedicated to questions about Schwartz's values, these are questions devoted to measuring the personal values previously defined by Schwartz [78-80].

Values 106, 107, and 130 are especially critical in relations between China and Spain since, in addition to being critical in China, they appear in the other 10\% extreme for Spain.

\section{Results}

\section{Risk Identification}

Once the critical values of Chinese culture have been identified, the next step is to discover the most common risks associated with cultural differences, which Spanish professionals must deal with in their business with China. For this task, the authors met with international project managers in a focus group, composed of 29 Spanish project managers experienced in China. They defined the risks and categorized them according to the selected cultural dimensions from Hofstede and Meyer. 
Next, they associated those risks with Chinese critical values, both from the literature and the WVS. The results are presented in Table 2.

Table 2. Chinese critical risk record in the Spanish projects associated with the WVS values.

\begin{tabular}{|c|c|c|c|}
\hline Category & Risk Id. & Risk Definition & Associated Value Id. from WVS \\
\hline \multirow{3}{*}{ Communication } & 1 & Public disciplinary actions & $73 ; 160 a$ \\
\hline & 2 & Misunderstanding direct communication & $160 \mathrm{i}$ \\
\hline & 3 & Providing imprecise project information & $160 \mathrm{i}$ \\
\hline \multirow{4}{*}{ Power distance } & 4 & Lack of preparation of leader & $160 \mathrm{i}$ \\
\hline & 5 & $\begin{array}{l}\text { No acceptance of young people in } \\
\text { responsibility positions }\end{array}$ & 63 \\
\hline & 6 & $\begin{array}{l}\text { Conflicts because of information exchange } \\
\text { without the supervisor's knowledge }\end{array}$ & 63 \\
\hline & 7 & $\begin{array}{c}\text { Problematic meetings with people from } \\
\text { different hierarchy }\end{array}$ & 63 \\
\hline \multirow{3}{*}{ Individualism } & 8 & $\begin{array}{l}\text { Holding a person responsible for a } \\
\text { group problem }\end{array}$ & $106 ; 107$ \\
\hline & 9 & $\begin{array}{l}\text { Lack of trust because of not investing enough } \\
\text { time in guanxi with Chinese CEOs }\end{array}$ & $73 ; 79$ \\
\hline & 10 & Not appreciating the search of common bonds & 79 \\
\hline Long-term orientation & 11 & Not scheduling the project stages properly & $160 \mathrm{i}$ \\
\hline \multirow{3}{*}{$\begin{array}{l}\text { Uncertainty } \\
\text { avoidance-Deciding }\end{array}$} & 12 & Ignorance about local laws & $63 ; 115$ \\
\hline & 13 & Not relying on risk response tools & \\
\hline & 14 & Unsuitable conflict management & 63 \\
\hline \multirow{3}{*}{ Persuading } & 15 & Not responding to appreciation or favors & $73 ; 79$ \\
\hline & 16 & Being inflexible with family commitments & $73 ; 79$ \\
\hline & 17 & $\begin{array}{l}\text { Emotional stress when demanding workers to } \\
\text { express opinions or feelings }\end{array}$ & $73 ; 160 a$ \\
\hline \multirow{3}{*}{ Trusting } & 18 & Not considering traditional Chinese values & $79 ; 115$ \\
\hline & 19 & $\begin{array}{l}\text { Criticizing managers in the presence of } \\
\text { their subordinates }\end{array}$ & \\
\hline & 20 & $\begin{array}{l}\text { Mistrust of implication of the project by the } \\
\text { Chinese company }\end{array}$ & $73 ; 107$ \\
\hline
\end{tabular}

The selection of the cultural dimensions was proposed by the authors according to previous research [41] and accepted during the focus group.

Table 2 presents the risks related to business between Spain and China. These need to be especially considered in businesses with China, as their impact could jeopardize a project's success.

This list is not exhaustive and should be reviewed per project. However, it will help project managers to identify intercultural risks in China.

\section{Discussion and Conclusions}

Management skills have always been considered to be an essential determinant of success in every project [20-29]. However, the influence of globalization and cross-cultural interaction in recent years has caused these skills to become critical.

The use of a cultural category when identifying risks puts into practice what other studies had previously defined on a theoretical level through the cultural risk breakdown structure [41]. For the use of this category of risks, the dimensions proposed in this study, or any that the executing organization of the project considers more appropriate, can be used. The important thing is that these risks associated with cultural differences are identified.

The fact that this identification also includes values is due to the link already introduced by Ott [81] between the way people act and the values inherent in their culture. In this study, these values were always present during the focus group.

Most of the risks identified belong to the area of personal relationships (risks 1 to 10 and 14 to 20). This is in line with the new proposals within project management in which more importance is given 
to the project manager's personal competences [20-29]. In fact, the Project Management Institute's own PMP (Project Management Professional) certification is adapting its exams to give more weight to this part.

The results of the research are of interest when it comes to the management of Spanish organizations that have projects in China. They can provide valuable help to select the most suitable training programs for their employees when executing projects in China. Results highlight the importance of cultural risks as it had been done by previous researchers $[6,39,69]$.

This paper presents previous studies about intercultural differences and how China and Spain are defined, analyzes the results from the World Values Survey (WVS), highlighting China and Spain's most critical values (Table 1) and finally identifies, through a focus group with 29 Spanish project managers experienced in leading projects in China, what the most critical risks are that could jeopardize the project from an intercultural point of view (Table 2).

The main contribution of this work is the identification of 20 risks commonly agreed among all project managers. It is considered as a valuable finding to improve the performance and the sustainability of Spanish projects in China, regardless of the type of project involved. Then, of course, each organization must complete the list of risks by looking at its own business risks and making the assessment according to its criteria.

This study has several limitations that can be addressed in future research. First, the Chinese national culture is considered stable, according to data from the WVS-6 (2010-2014). Although there has been a slow evolution of values since the beginning of this survey (1981), stability can be assumed. However, the dramatic development of China could cause minor variations in this. In this regard, future research should compare the results achieved in this work with those obtained from the WVS-7. Second, risks that have been identified have been considered only for their negative meanings. Thus, identifying positive risks in future studies would provide a series of opportunities that could drive business success. Thus, it would also contribute to this field so rarely explored and claimed by the project management or risk management main guidelines [5-9]. Finally, it would be quite useful to assess these risks, so that they can be prioritized. In this first research, it was not included since following the principles defined by the ISO 31.000:2018, the risk management has to be tailored to each organization [5], and it implies that each one establishes its own assessment criteria. It would be very interesting if this evaluation were carried out on different Western countries operating in China, to contrast with previous studies on how culture influences risk assessment [64,73].

Author Contributions: Conceptualization, I.O.-M. and R.R.-R.; methodology, X.M.-B. and R.R.-R.; validation, I.O.-M. and L.B.-S.; investigation R.R.-R., I.O.-M. and X.M.-B.; writing-original draft preparation, R.R.-R. and I.O.-M.; writing-review and editing, R.R.-R.; supervision, I.O.-M. and L.B.-S. All authors have read and agreed to the published version of the manuscript.

Funding: This research received no external funding.

Acknowledgments: The authors would like to thank the project managers participating in the focus group for their time and contributions to this research. Likewise, we are also grateful for the excellent reception of the presentation of this research at the 24th International Congress on Project Management and Engineering. Finally, many thanks to the reviewers for their useful comments to improve the quality of this work.

Conflicts of Interest: The authors declare no conflict of interest.

\section{References}

1. Giorgi, G.; Lecca, L.I.; Ariza-Montes, A.; Di Massimo, C.; Campagna, M.; Finstad, G.L.; Arcangeli, G.; Mucci, N. The Dark and the Light Side of the Expatriate's Cross-Cultural Adjustment: A Novel Framework Including Perceived Organizational Support, Work Related Stress and Innovation. Sustainability 2020, 12, 2969. [CrossRef]

2. Martínez-Perales, S.; Ortiz-Marcos, I.; Juan Ruiz, J.; Lázaro, F.J. Using Certification as a Tool to Develop Sustainability in Project Management. Sustainability 2018, 10, 1408. [CrossRef] 
3. International Organization for Standardization. ISO 14001:2015 Environmental Management Systems-Requirements with Guidance for Use; ISO: Geneva, Switzerland, 2015.

4. International Organization for Standardization. ISO 9001:2015 Quality Management Systems—Requirements; ISO: Geneva, Switzerland, 2015.

5. International Organization for Standardization. ISO 31000:2018 Risk Management_Guidelines; ISO: Geneva, Switzerland, 2018.

6. Yan, B.R.; Dong, Q.L.; Li, Q. Research on Risk Measurement of Supply Chain Emergencies in International Capacity Cooperation. Sustainability 2019, 11, 5184. [CrossRef]

7. Wang, C.L. Guanxi vs. relationship marketing: Exploring underlying differences. Ind. Market. Manag. 2007, 36, 81-86. [CrossRef]

8. Kerzner, H. Project Management: A Systems Approach to Planning, Scheduling, and Controlling; Wiley: Hoboken, NJ, USA, 2017.

9. Project Management Institute. A Guide to the Project Management Body of Knowledge, 6th ed.; Project Management Institute: Newtown Square, PA, USA, 2017.

10. Pollack, J. The changing paradigms of project management. Int. J. Proj. Manag. 2007, 25, 266-274. [CrossRef]

11. Cicmil, S.; Williams, T.; Thomas, J.; Hodgson, D. Rethinking project management: Researching the actuality of projects. Int. J. Proj. Manag. 2006, 24, 675-686. [CrossRef]

12. Winter, M.; Smith, C.; Cooke-Davies, T.; Cicmil, S. The importance of 'process' in rethinking project management: The story of a UK government-funded research network. Int. J. Proj. Manag. 2006, 24, 650-662. [CrossRef]

13. Blomquist, T.; Hällgren, M.; Nilsson, A.; Söderholm, A. Project-as-practice: In search of project management research that matters. Proj. Manag. J. 2010, 41, 5-16. [CrossRef]

14. Svejvig, P.; Andersen, P. Rethinking project management: A structured literature review with a critical look at the brave new world. Int. J. Proj. Manag. 2015, 33, 278-290. [CrossRef]

15. Gareis, R.; Huemann, M.; Martinuzzi, A. Relating sustainable development and PM: A conceptual model. In Proceedings of the PMIßResearch Conference 2010: Defining the Future of PM, Washington, DC, USA, 11-14 July 2010; PM Institute: Newtown Square, PA, USA, 2010.

16. Silvius, A.J.G.; Schipper, R. A Conceptual Model for Exploring the Relationship between Sustainability and Project Success. Proced. Comput. Sci. 2015, 64, 334-342. [CrossRef]

17. Martens, M.L.; Carvalho, M.M. Sustainability and Success Variables in the PM Context: An Expert Panel. Proj. Manag. J. 2016, 47, 24-43. [CrossRef]

18. Martens, M.L.; Carvalho, M.M. Key Factors of Sustainability in PM Context: A Survey Exploring the Project Managers' Perspective. Int. J. Proj. Manag. 2017, 35, 1084-1102. [CrossRef]

19. Uribe, D.; Ortiz-Marcos, I.; Uruburu, A. What Is Going on with Stakeholder Theory in Project Management Literature? A Symbiotic Relationship for Sustainability. Sustainability 2018, 10, 1300. [CrossRef]

20. Anbari, F.T.; Carayannis, E.G.; Voetsch, R.J. Post-project reviews as a key project management competence. Technovation 2008, 28, 633-643. [CrossRef]

21. Ballesteros-Sánchez, L.; Ortiz-Marcos, I.; Rodriguez-Rivero, R. The project managers' challenges in a projectification environment. Int. J. Manag. Proj. Bus. 2019, 12, 522-544. [CrossRef]

22. Crawford, L.H.; Cooke-Davies, T.J.; Hobbs, J.B.; Labuschagne, L.; Remington, K.; Chen, P. Governance and support in the sponsorship of projects and programs. In Proceedings of the Project Management Institute (PMI) Research Conference, Warsaw, Poland, 13-16 July 2008.

23. Fisher, E. What practitioners consider to be the skills and behaviours of an effective people project manager. Int. J. Proj. Manag. 2011, 29, 994-1002. [CrossRef]

24. Jones, R.A.; Rafferty, A.E.; Griffin, M.A. The executive coaching trend: Towards more flexible executives. Leadersh. Org. Dev. J. 2006, 27, 584-596. [CrossRef]

25. Müller, R.; Turner, R. Leadership competency profiles of successful project managers. Int. J. Proj. Manag. 2010, 28, 437-448. [CrossRef]

26. Ortiz-Marcos, I.; Cobo Benita, J.R.; Mataix Aldeanueva, C.; Uruburu Colsa, A. Competency training for managing international cooperation engineering projects. Proj. Manag. J. 2013, 44, 88-97. [CrossRef]

27. Papke-Shields, K.E.; Beise, C.; Quan, J. Do project managers practice what they preach, and does it matter to project success? Int. J. Proj. Manag. 2010, 28, 650-662. [CrossRef]

28. Thite, M. Leadership styles in information technology projects. Int. J. Proj. Manag. 2000, 18, 235-241. [CrossRef] 
29. Yang, L.R.; Huang, C.F.; Wu, K.S. The association among project manager's leadership style, teamwork and project success. Int. J. Proj. Manag. 2011, 29, 258-267. [CrossRef]

30. Papanikolaou, M.; Xenidis, Y. Risk-Informed Performance Assessment of Construction Projects. Sustainability 2020, 12, 5321. [CrossRef]

31. Carvalho, M.M.; Rabechini Junior, R. Impact of Risk Management on Project Performance: The Importance of Soft Skills. Int. J. Prod. Res. 2015, 53, 321-340. [CrossRef]

32. Chapman, C.; Ward, S. Estimation and Evaluation of Uncertainty: A Minimalist First Pass Approach. Int. J. Proj. Manag. 2000, 18, 369-383. [CrossRef]

33. Ward, S.; Chapman, C. Transforming Project Risk Management into Project Uncertainty Management. Int. J. Proj. Manag. 2003, 21, 97-105. [CrossRef]

34. Hillson, D. Extending the Risk Process to Manage Opportunities. Int. J. Proj. Manag. 2002, 20, $235-240$. [CrossRef]

35. Atkinson, R.; Crawford, L.; Ward, S. Fundamental Uncertainties in Projects and the Scope of Project Management. Int. J. Proj. Manag. 2006, 24, 687-698. [CrossRef]

36. Perminova, O.; Gustafsson, M.; Wikstrom, K. Defining Uncertainty in Projects-A New Perspective. Int. J. Proj. Manag. 2008, 26, 73-79. [CrossRef]

37. Cleden, D. Managing Project Uncertainty; Gower: Farnham, UK, 2009.

38. Bredillet, C.; Yatim, F.; Ruiz, P. Project management deployment: The role of cultural factors. Int. J. Proj. Manag. 2010, 28, 183-193. [CrossRef]

39. Liu, J.; Meng, F.; Fellows, R. An exploratory study of understanding project risk management from the perspective of national culture. Int. J. Proj. Manag. 2015, 33, 564-575. [CrossRef]

40. Rees-Caldwell, K.; Pinnington, A.H. National culture differences in project management: Comparing British and Arab project managers' perceptions of different planning areas. Int. J. Proj. Manag. 2013, 31, $212-227$. [CrossRef]

41. Rodríguez-Rivero, R.; Ortiz-Marcos, I.; Ballesteros-Sánchez, L.; Romero, J. The opportunity to improve psychological competences of project managers in international businesses. Psychol. Mark. 2018, 35, 150-159. [CrossRef]

42. Hofstede, G.; Hofstede, G.J.; Minkov, M. Cultures and Organizations: Software of the Mind, 3rd ed.; McGraw-Hill: New York, NY, USA, 2010.

43. Gregg, P.M.; Banks, A.S. Dimensions of Political Systems: Factor Analysis of a Cross-Polity Survey. Am. Polit. Sci. Rev. 1965, 59, 602-614. [CrossRef]

44. Lynn, R.; Hampson, S.L. National differences in extraversion and neuroticism. Br. J. Soc. Clin. Psychol. 1975, 14, 223-240. [CrossRef] [PubMed]

45. Hofstede, G.; Bond, M.H. The Confucius connection: From cultural roots to economic growth. Organ. Dyn. 1988, 16, 4-21. [CrossRef]

46. Minkov, M. What Makes Us Different and Similar: A New Interpretation of the World Values Survey and Other Cross-Cultural Data; Klasika i Stil: Sofia, Bulgaria, 2007.

47. Kirkman, B.L.; Lowe, K.B.; Gibson, C.B. A quarter century of Culture's Consequences: A review of empirical research incorporating Ho cultural fstede's values framework. J. Int. Bus. Stud. 2006, 37, 285-320. [CrossRef]

48. Müller, R.; Turner, J.R. Cultural differences in project owner-manager communication. In Proceedings of the Project Management Institute Conference Proceedings, London, UK, 11-14 July 2004.

49. Lewis, R.D. When Cultures Collide. Leading Successfully Across Cultures, 4th ed.; Nicholas Brealey Publishing: London, UK, 2018.

50. Meyer, E. The Culture Map; Public Affairs: New York, NY, USA, 2015.

51. Trompenaars, F. Riding the Waves of Culture: Understanding Cultural Diversity in Business; Nicholas Brealey: London, UK, 1993.

52. ONTSI (Observatorio Nacional de las Telecomunicaciones y de la Sociedad Digital). Barómetro de emprendimiento en España; Ministerio de Asuntos Económicos y Transformación Digital: Madrid, Spain, 2019. Available online: http://www.ontsi.red.es/es/dossier-de-indicadores-pdf/Barometro-de-emprendimiento\#: $\sim\{\}:$ text $=$ En $\% 20 t \%$ C3\%A9rminos $\% 20$ generales $\% 2 C \% 201$ s $\% 20$ indicadores $\% 20$ sobre $\% 20$ emprendimiento $\%$ 20para,emprendedora $\% 2$ C $\% 20$ frente $\% 20$ al $\% 206 \% 2$ C4\%20\%25\%20de $\% 201$ os $\% 20$ espa $\%$ C3 $\%$ B1oles (accessed on 16 August 2020). 
53. Juárez, A.; Sancho, A.; Gutiérrez, C. Cultural Differences and Interferences between China and Spain in the Tourism Industry. Balance 2011, 12, 14-879.

54. Bader, A.K.; Froese, F.J.; Achteresch, A.; Behrens, S. Expatriates' influence on the affective commitment of host country nationals in China: The moderating effects of individual values and status characteristics. Eur. J. Int. Manag. 2017, 11, 181-200. [CrossRef]

55. Chen, Z.X.; Francesco, A.M. Employee demography, organizational commitment, and turnover intentions in China: Do cultural differences matter? Hum. Relat. 2000, 53, 869-887. [CrossRef]

56. Leung, K.; Brew, F.P.; Zhang, Z.X.; Zhang, Y. Harmony and conflict: A cross-cultural investigation in China and Australia. J. Cross Cult. Psychol. 2011, 42, 795-816. [CrossRef]

57. Park, J.; Kim, D.Y.; Zhang, C. Understanding cross-national differences in risk through a localized cultural perspective. Cross Cult. Res. 2016, 50, 34-62. [CrossRef]

58. Shin, S.K.; Ishman, M.; Sanders, G.L. An empirical investigation of socio-cultural factors of information sharing in China. Inform. Manag. 2007, 44, 165-174. [CrossRef]

59. Chen, Y.F.; Tjosvold, D.; Su, S.F. Goal interdependence for working across cultural boundaries: Chinese employees with foreign managers. Int. J. Intercult. Relat. 2005, 29, 429-447. [CrossRef]

60. Aven, T. On the new ISO guide on risk management terminology. Reliab. Eng. Syst. Saf. 2011, 96, 719-726. [CrossRef]

61. Aven, T. On how to define, understand and describe risk. Reliab. Eng. Syst. Saf. 2010, 95, 623-631. [CrossRef]

62. Olechowski, A.; Oehmen, J.; Seering, W.; Ben-Daya, M. The professionalization of risk management: What role can the ISO 31000 risk management principles play? Int. J. Proj. Manag. 2016, 34, 1568-1578. [CrossRef]

63. Kosovac, A.; Davidson, B.; Malano, H. Are We Objective? A Study into the Effectiveness of Risk Measurement in the Water Industry. Sustainability 2019, 11, 1279. [CrossRef]

64. De Camprieu, R.; Desbiens, J.; Feixue, Y. Cultural differences in project risk perception: An empirical comparison of China and Canada. Int. J. Proj. Manag. 2007, 25, 683-693. [CrossRef]

65. Hong, S.J.; Lee, S.H. Reducing cultural uncertainty through experience gained in the domestic market. J. World Bus. 2015, 50, 428-438. [CrossRef]

66. Barkema, H.G.; Bell, J.H.J.; Pennings, J.M. Foreign entry, cultural barriers, and learning. Strateg. Manag. J. 1996, 17, 151-166. [CrossRef]

67. Benito, G.R.G.; Gripsrud, G. The expansion of foreign direct investments: Discrete rational location choices or a cultural learning process? J. Int. Bus. Stud. 1992, 23, 461-476. [CrossRef]

68. Blair, B.; Lovecraft, A.L. Risks Without Borders: A Cultural Consensus Model of Risks to Sustainability in Rapidly Changing Social-Ecological Systems. Sustainability 2020, 12, 2446. [CrossRef]

69. De Carvalho, M.M.; Patah, L.A.; Bido, D.D. Project management and its effects on project success: Cross-country and cross-industry comparisons. Int. J. Proj. Manag. 2015, 33, 1509-1522. [CrossRef]

70. Xue, W.; Hine, D.W.; Loi, N.M.; Thorsteinsson, E.B.; Phillips, W.J. Cultural worldviews and environmental risk perceptions: A meta-analysis. J. Environ. Psychol. 2014, 40, 249-258. [CrossRef]

71. Sagiv, L.; Schwartz, S.H. Cultural values in organisations: Insights for Europe. Eur. J. Int. Manag. 2007, 1, 176-190. [CrossRef]

72. Gunkel, M.; Schlaegel, C.; Taras, V. Cultural values, emotional intelligence, and conflict handling styles: A global study. J. World Bus. 2016, 51, 568-585. [CrossRef]

73. Liu, X. The Role of Enterprise Risk Management in Sustainable Decision-Making: A Cross-Cultural Comparison. Sustainability 2019, 11, 2939. [CrossRef]

74. Heine, S.J. An exploration of cultural variation in self-enhancing and self-improving motivations. In Crosscultural Differences in Perspectives on the Self; Murphy-Berman, V., Berman, J.J., Eds.; Nebraska Symposium on Motivation; University of Nebraska Press: Lincoln, Nebraska, 2003; Volume 49, pp. 101-128.

75. Autio, E.; Pathak, S.; Wennberg, K. Consequences of cultural practices for entrepreneurial behaviors. J. Int. Bus. Stud. 2013, 44, 334-362. [CrossRef]

76. Hofstede Insights: The 6-D Model. Available online: http://www.hi.hofstede-insights.com/national-culture (accessed on 16 March 2020).

77. World Value Survey. Available online: http://www.worldvaluessurvey:wvs.jsp (accessed on 5 November 2019).

78. Schwartz, S.H. Cultural value differences: Some implications for work. Appl. Psychol. Int. Rev. 1999, 48, 23-47. [CrossRef] 
79. Schwartz, S.H. Mapping and interpreting cubltural differences around the world. In Comparing Cultures, Dimensions of Culture in a Comparative Perspective; Vinken, H., Soeters, J., Ester, P., Eds.; Brill: Leiden, the Netherlands, 2004; pp. 43-73.

80. Schwartz, S.H. A theory of cultural value orientations: Explication and applications. Comput. Sociol. 2006, 5, 137-182. [CrossRef]

81. Ott, U.F. The art and economics of international negotiations: Haggling meets hurrying and hanging on in buyer-seller negotiations. J. Innov. Knowl. 2016, 1, 51-61. [CrossRef]

82. Hofstede, G. Dimensionalizing cultures: The Hofstede model in context. Online Read. Psychol. Cult. 2011, 2, 1-26. [CrossRef]

83. Fan, Y. A classification of Chinese culture. Cross Cult Manag. 2000, 7, 3-10. [CrossRef]

(C) 2020 by the authors. Licensee MDPI, Basel, Switzerland. This article is an open access article distributed under the terms and conditions of the Creative Commons Attribution (CC BY) license (http://creativecommons.org/licenses/by/4.0/). 